\title{
Abolition of Child Marriage Practices in Indonesia According to the United Nations Convention on the Rights of the Child
}

Iin Karita Sakharina*, Aidir Amin Daud

Associate Professor, Faculty of Law, Hasanuddin University, Indonesia

DOI: $10.36348 /$ sijlcj.2020.v03i06.009

| Received: 15.06 .2020 | Accepted: 22.06.2020 | Published: 26.06.2020

*Corresponding author: Iin Karita Sakharina

\section{Abstract}

The practice of child marriage in Indonesia is still prevalent to this day, and this is a serious problem. Indonesia still ranks second among Asian countries as a country that practices marriage against children after Cambodia. Generally, the practice of child marriage conducted in Indonesia is against children especially girls who are in rural areas and come from poor families. The purpose of this study was to see how the practice of child marriage of girls, especially in Indonesia and what efforts should be made to eliminate the practice of child marriage. This paper will discuss the steps that must be taken to eliminate the practice of child marriage in Indonesia, especially against girls as this becomes a serious and very detrimental issue, especially for girls. Because generally they are forced to undergo this. This research uses normative research type with qualitative method. The results show that the practice of marriage to girls in Indonesia occurs due to several factors, such as poverty, lack of education, and matchmaking tradition in some areas. The practice of marriage of girls is also contrary to the UN Convention on the Rights of the Child (UNCRC) that has been ratified by the Government of Indonesia through Presidential Decree of the Republic of Indonesia Number 36 Year 1990, besides the Indonesian Government has also issued Law of the Republic of Indonesia Number 35 Year 2014 on Amendment to Law of the Republic of Indonesia Number 23 Year 2002 on Child Protection, then refers also to the Marriage Law in Indonesia, Number 1 Year 1974 on Marriage. So in the opinion of the authors, the practice of marriage of children to girls in some areas in Indonesia is a form of violation of human rights to children according to the convention of children's rights which has also been ratified by the Indonesian government for more than 25 years so that there should be efforts made by the Government as a form of implementation of the UNCRC that has been ratified in the case of the protection and fulfilment of the rights of the child on the basis of the Convention, the author believes that the practice of marriage against girls should be abolished because it has been very long and very harmful for girls in Indonesia.

Keywords: Abolishment, Children Marriage, Indonesia, UNCRC.

Copyright @ 2020: This is an open-access article distributed under the terms of the Creative Commons Attribution license which permits unrestricted use, distribution, and reproduction in any medium for non-commercial use (NonCommercial, or CC-BY-NC) provided the original author and source are credited.

\section{INTRODUCTION}

The practice of child marriage in Indonesia is still happening to this day. Even Indonesia ranks 37 th (thirty seven) highest in early marriage rate among countries in the world, and secondly after Cambodia among The Association of Southeast Asian Nations (ASEAN) countries [1]. According to Psychiatrist from Al-Islam Hospital Bandung, Untung Sentosa said Indonesia ranked 37th in the world, and ranked 2nd in Asia in the percentage of early marriage or pregnancy in adolescents. This figure is a fantastic figure, because it shows that Indonesia is one country with a high unexpected marriage rate [2]. Although the Government has issued a ban on the practice of child marriage, but still there are many who do the marriage, especially in areas in several Provinces in Indonesia.
The most horrendous and viral case in some media was the marriage case of a pair of children that occurred in April 2018 in Bantaeng district, one of the districts of South Sulawesi Province, where the two couples were children of 15 years old, while a 14-yearold woman, escorted by her family, wants to register their marriage to the Ministry of Religious Affairs office to obtain legal marriage certification, but fortunately it has been successfully thwarted by the KUA by not giving permission to marry. Then there is another case, there is also South Sulawesi Province, Sinjai district, where the male is 21 years old but the woman is known to be 12 years old[3].

According to Jakarta Central Bureau of Statistics reported, there are five provinces in Indonesia that have high rates of marriage or underage rates, 
namely West Sulawesi, Papua, Central Sulawesi, South Sulawesi and West Papua provinces, where marriage percentage of married girls before the age of 15 years tends to 50,000 per year[4].

Early or underage marriages, at an age not eligible for marriage, may be canceled or foiled by the Government Party whenever they wish to apply for permission or register their marriage to KUA for Muslims to obtain legal authorization. But the problem is when to get marital status legally it was rejected because it is known that the marriage of one of them or both are still under age and they ultimately still choose to make a religious marriage, although not get legal recognition of her marriage.

The problem is precisely here, because it means a marriage is still under age even if the marriage is not registered legally anymore. It is precisely this practice that is more harmful and detrimental, especially if the marriage is done by force and the victim is a girl who has not been 18 years old. For whatever the name of marriage has taken place, and inevitably, the girl has changed her status from child to adult, where she has to assume more heavy responsibilities as an adult female, not to mention the maturity of her reproduction is not perfect then if she is pregnant and has to give birth so it would be dangerous for the girl's health because medically her reproductive organs are not fully ripe and not ready for childbirth.

Then from the side of the Psychological Maturity is also certainly a daughter who has not been 18 years old is not fully ready to take care of the household, take care of the children, because in terms of age alone he is also immature. In addition, early marriage causes children, especially girls, to be disconnected from their rights as children to get their freedom as children, disconnected to get a higher education, and of course this will affect the future. One of them is that women will become very dependent on their husbands, economically and financially, because by not having enough education women will not be able to do nothing but just be housewives and take care of their families. Of course this will be detrimental to women because her husband will use it as a weapon to act arbitrarily against his wife, one of them by doing violence, or marry again with another woman without asking permission from the first wife or without thinking about how his first wife, because if something like this happens, then the woman who has a financially dependent on her husband can not do anything but resigned to all the actions her husband made against her. Of course this is contrary to the Rights of Women as Indonesia has ratified international conventions relating to the rights of women, such as Convention on Elimination against Women (CEDAW) ratified in Law of the Republic of Indonesia Number 7 Year 1984 on All Forms of Elimination of Discrimination against Women. Then Indonesia has also participated in the signing of the Beijing Declaration on Anti-Violence against Women.

While in other hand, it is not uncommon or a lot of marriages occur under the age was done with coercion, especially against girls. This coercion is done by parents who agree to marry off their children despite being underage for various reasons, one of which is the economic reason, because of the poverty that occurs in Indonesian society, causing them to take this path, assuming that if girls have been married especially if the applying is the dating of parties who are financially excessive the economic burden of the parents of the daughter is gone or even be helped by the marriage of the daughter. In the case of underage marriages, the most frequent victims are the daughters, as most of the cases that have occurred, girls are married early and forcibly, assuming that girls are merely home moms ladder and not a breadwinner so no need to get high education and can be married quickly although underage. This is of course contrary to CEDAW where there is discrimination against the treatment of girls and boys. Boys because they are often assumed to be the head of the household in their family and become the breadwinner will not be forced to marry under age, and given the freedom to get the highest education for the future when they grow up.

Marital age of children in rural areas is one third higher than in urban areas (29.2 percent and 19.0 percent respectively in 2012). However, rural areas have shown a decline in the percentage of marriage-age children from 33.5 per cent in 2008 to 29.2 per cent in 2012, while urban areas show little increase, from 18.8 per cent to 19.0 per cent over the period the same year [5].

From the problems above, it is clear that the practice of early marriage is still ongoing in Indonesia even though the government has banned and did not give permission legally for its authorization but it is not possible to do religiously, where this is of course still detrimental, especially for children women who often become victims so need to look for a firm solution so that the practice of underage marriage can really be eliminated in Indonesia

\section{METHOD}

The method of the study will be data from literatures, cases, journals and reports which conducted by using the qualitative description which through selecting the correct data in order to explain, states the fact clearly in addition to avoid using irrelevant data.

\section{RESULTS AND DISCUSSION}

The results show that the practice of marriage to girls in Indonesia occurs due to several factors, such as poverty, lack of education, and matchmaking tradition in some areas. The results of Plan Indonesia's 
work in collaboration with the Centre for Population and Policy Studies (PSKK) UGM 2011 on 'Early Marriage Practices in Indonesia' in eight areas: Indramayu, Grobogan, Rembang, Tabanan, Dompu, Sikka, Lembata and the Middle East South (TTS) indicates that the mean of mating age across the study area is 16 years [6].

According to the Law of the Republic of Indonesia Number 1 Year 1974 on Marriage allows 16year-old girls to marry, as mentioned in Article 7 paragraph 1, "Marriage is only permitted if the men have reached 19 (nineteen) years, and the women have reached 16 (sixteen) years"[7]. In addition, according to the Convention on the Rights of the Child (CRC), marriage is a marriage that occurs under the age of 18 years.

According to The International Committee of the Red Cross (ICRC) is for the purpose of present convention, a child means every human being below the age of eighteen years unless the law applicable to the child, majority is attained earlier[8].

Meanwhile, Law of the Republic of Indonesia Number 35 Year 2014 on Amendment to Law of the Republic of Indonesia Number 23 Year 2002 on Child Protection defines a child as a person not yet 18 (eighteen) years of age, including a child still in the womb[9].

Then Article 330 of the Civil Code (Burgerlijk Wetboek) defines children based on their maturity. That a person is immature if it has not reached the age of 21 (twenty one) years and is not married first [10].

Whereas customary law dictates that one's maturity is not of age, but the measure used is:

a. can work alone;

b. able to do what is required in the life of the community; and

c. can take care of their own wealth[11].

The practice of child marriage is also contrary to the Convention on the Rights of the Child that has been ratified by the Government of Indonesia through Presidential Decree No. 36 of 1990, where the Convention on the Rights of the Child contains 10 (ten) basic principles:[12]

1. The child shall be entitled to enjoy all his rights in accordance with the provisions contained in this Declaration. That every child without exception shall be guaranteed his rights without distinction of ethnicity, colour, sex, language, religion, political or other views, nationality or social rank, poorer, birth or other status, his family;

2. The child shall have the right to special protection, and shall have the opportunity guaranteed by law and other means to enable him to develop himself physically, psychologically, morally, spiritually and socially in a healthy, normal situation according to his freedom and dignity;

3. The child from birth has the right to name and nationality;

4. The child shall have the right and shall be guaranteed by society to grow and develop in a healthy manner;

5. Children who are physically disabled, mentally and socially disadvantaged by a particular circumstance must obtain special education, care and treatment;

6. In order for the child's personality to grow maximally and harmoniously, he needs compassion and attention. As much as possible he was raised under the care and responsibility of his own parents, and however should be endeavoured to remain in a loving atmosphere. Physically and mentally healthy;

7. The child is entitled to free compulsory education at least at the primary school level. They shall have the protection which may increase their general knowledge, or enable it on the basis of equal opportunity to develop their personal capacities, opinions and feelings of moral and social responsibility, so that they may become useful members of society. The child also has the freedom to play and recreate directed for educational purposes, the public and the government authorities should seek to improve the exercise of this right

8. Under no circumstances shall the child take precedence in receiving protection and help;

9. The child shall be protected from as a form of omission, violence, exploitation. It shall not be subject to trade, meaning that a child shall not work before a certain age; he shall not be engaged in work which may prejudice his health or education, nor may affect the development of his body, soul or morals;

10. The child shall be protected from acts that lead to other forms of social discrimination, religion or other forms of discrimination.

This principle is a "declaratory statement", which is more of a "binding piece of international legislation", which is a more binding and detailed provision and set forth in the articles of the convention. Therefore, these basic principles of child protection are a reflection of a holistic approach, meaning that the rights of the child are not narrowly seen, but should be seen broadly, within the scope of human rights protection, such as civil, political, economic, social and cultural rights [13]. For that reason, the practice of early marriage conducted in some areas of Indonesia to this day contradicts the ten basic principles of protection and fulfilment of children's rights that have been ratified by the Government of Indonesia through Presidential Decree of the Republic of Indonesia Number 36 Year 1990. Of course as a State Party, Indonesia has the obligation to implement anything listed in the article. 
In addition, the Government of Indonesia has also issued Law of the Republic of Indonesia Number 35 Year 2014 on Amendment to Law of the Republic of Indonesia Number 23 Year 2002 on Child Protection, and also refers to the Marriage Law in Indonesia, Law of the Republic of Indonesia Number 1 Year 1974 on Marriage. So in the opinion of the author, the practice of marriage of children to girls in some areas in Indonesia is a form of violation of human rights to children according to the convention of children's rights which has also been ratified by the Indonesian government for more than 25 years so that there should be efforts made by the Government as a form of implementation Of the Convention on the Rights of the Child that has been ratified in the case of the protection and fulfilment of the rights of the child on the basis of the Convention, the writer believes that the practice of marriage against girls should be abolished because it has been very long and very harmful for girls in Indonesia.

The impact or consequence of early marriage is also more harm than good, especially for girls who are forced to undergo this early marriage. Because as mentioned above that after marriage it is automatic that these girls have to be housewives, who must take care of their husbands and children, while both physically and psychically they are not ready to be burdened with responsibilities as adults. So it is not uncommon even cause chaos in the household where the return of girls who are blamed for the occurrence of failure or chaos that arise in the household. Girls often experience stress when they leave their families and take responsibility for their own families. In addition, child marriage also has adverse effects on girls as vulnerable as domestic violence. According to Plan's findings, as many as $44 \%$ of girls who have early marriage experience high levels of domestic violence (KDRT). The rest, $56 \%$ of girls experience domestic violence in low frequency. In addition to the high number of domestic violence [14].

From Centre Bureau Statistic Report on Child Marriage Analysis, it is mentioned that child marriage practices often have adverse impacts on health, education, economic status, the safety of girls and their children in the future and also cause harm to the community. The disadvantage in the community is that marriage of child age not only underlies, but also encourages gender inequality in society. Child marriage can lead to continuing poverty cycles, increased illiteracy, poor health to future generations, and depriving wider community productivity both in the short and long term [15].

Furthermore mentioned that the most important impact is on health, where girls in the age of 10-14 years have a 5 times greater risk of dying in pregnancy and childbirth than girls at the age of 2024[16]. While under CEDAW clearly mentioned that any distinction, exclusion or restriction made on the basis of sex which has the effect or purpose of impairing or multifying the women, irrespective of their marital status, on a basis of equality of men and women, of human rights and fundamental freedoms in the political, economic, social, cultural, civil or any other field [17].

So that the imposition of marriage on a child is also one form of discrimination against girls, because by assuming that girls do not need to go to high school because later they only become administrators in the household and not the main breadwinner, and do not provide equal opportunities for children women to enjoy their childhood and get a decent education as well as boys.

A report from the Jakarta Central Bureau of Statistics on child marriage analysis also mentions that $85 \%$ of girls terminate their education after marriage [18] because once they get married, the access to get education is immediately terminated, because they are considered to be a wife who must take care of his household, care and devoted to her husband and later became the mother who has full responsibility to take care of their household.

When seen the problems have mentioned above, the practice of child marriage is obviously against with CEDAW, which is clearly mentioned under Article 16 about the right of women in marriage: [19].

a. The same rights to enter into marriage

b. The same right freely to choose a spouse and to enter into marriage only with their free and full consent

c. The same right and responsibility during marriage and its dissolution

d. The same rights and responsibility as parent, irrespective of their marital status, in matters relating to their children: in all cases the interest of the children shall be paramount;

e. The same right to decide freely and responsibly on the number and spacing of their children and to have access to information, education, and means to enable them to exercise these rights

f. The same rights and responsibility with regard to guardianship, ward ship, trusteeship and adoption of children, or similar institution where these concepts exist in nationality legislation; In all cases the interest of the children shall be paramount;

g. The same personal rights as husband and wife; including the right to choose a family name, a profession and occupation;

h. The same rights for a spouse in respect of the ownership, acquisition, management, administrative, enjoyment and disposition of property free charge or a valuable consideration 
According to the Article 16 mentioned above means that all the points provided by the articles can be interpreted as the right of the women when entered it into the marriage, since Article 16 of the CEDAW had mentioned it clearly [20]. So refer to the Article 16, including underage marriage also can not be imposed because it is contrary to CEDAW, where the Convention has also been ratified by the Government of Indonesia since 1987 into the Law of the Republic of Indonesia Number 7 Year 1987. While the ratification of these convention obliges the government of Indonesia to adopt measure to eliminate all forms of discrimination against women [21].

Apart from that, because the issue of marriage involves children in it is clear that related to the issue of child protection, as the Government's commitment, therefore must also be perceived three things that become priorities in achieving the direction of the

Government's policy of increasing protection by the Government:[22]

1. Improving the quality of growth and survival of children, among others, through improving the accessibility and quality of early childhood development programs; improving the quality of children's health; and improvement of reproductive health education for adolescents.

2. Child protection from all forms of violence and discrimination, including through: improvement of rehabilitation and protection of children; increased protection for child labour and the elimination of child labour; and increased protection for children facing the law.

3. To increase the institutional capacity of child protection, among others, through the preparation and harmonization of legislation related to child protection; improvement of child protection implementation capacity; improvement of provision of data and information on child protection; and enhanced coordination and partnership among stakeholders on the fulfilment of children's rights, both national and international law.

Even the Law of the Republic of Indonesia Number 35 Year 2014 on the amendment to Law of the Republic of Indonesia Number 23 Year 2002 on Child Protection mandates that the State, Government, Local Government, Community, Family and Parent are obliged to provide protection and guarantee the fulfilment of the rights of the Child in accordance with its duties and responsibilities. Child Protection has not provided guarantee for the Child to get the treatment and opportunity that suits their needs in various areas of life, so that in implementing efforts to protect the Rights of the Child by the Government must be based on the principles of human rights that is respect, fulfilment and protection on the Rights of the Child [23].

\section{CONCLUSION}

Whereas based on the above explanation, it is clear that the practice of child marriage especially for girls is not profitable at all, even impressed many of the losses that girls get, including the impact on the health of girls and also the separation of the rights of girls to enjoy their freedom as children, especially the right to education high, the disconnection of girls' rights to a high education means that girls do not have a better chance of getting a better job and that means married girls have an economic and financial dependence on their husbands, the husband becomes more dominant in terms of earning a living and not infrequently the impact is to make the husband becomes arbitrary against his wife and not infrequently violence against women or wives.

That the Government should be encouraged to explicitly eliminate the practice of child marriage, especially for girls, whether the girls are forced to marry early or on their own will because there is no advantage of this early marriage practice, even many negative impacts occur.

The government must strictly prohibit the marriage of girls to the people who are still doing this either by legally marriage and marriage there and religion because whatever the name is still married whose impact is still detrimental to girls especially if the marriage was only done by custom or religion only then there is no protection at all against the married daughter.

The government through the competent authorities must actively socialize to provide understanding to the public the adverse impact of early marriage especially on girls who are forced to marry.

In addition to avoiding or terminating this practice, the Government should actively socialize and create policies that apply equal rights to access education for girls, so the assumption that having girls is a burden to society is wrong because if girls are entitled equal access for boys, he can also be equally advanced with boys and may even become the main breadwinner for his family, so that all forms of discrimination against the treatment of daughters should be abolished.

\section{REFERENCES}

1. https://ifestyle.kompas.com/read/2015/12/13/1100 00623/Indonesia.Urutan.Kedua.Tertinggi.Pernikah an.Remaja, accessed on June 21, 2018.

2. http://www.pikiran-rakyat.com/bandungraya/2015/06/07/330142/pernikahan-dini-diindonesia-peringkat-dua-di-asia, accessed on June $21,2018$.

3. https://www.idntimes.com/news/indonesia/indiana malia/5-pernikahan-dini-di-indonesia-yang-sita- 
perhatian-publik-ada-yang-4-hari-cerai/full, accessed on June 21, 2018.

4. BPS Jakarta. (2016). Kemajuan Yang Tertunda, Analisis data Perkawinan Usia anak di Indonesia, BPS Jakarta funded By United Nations Children's Fund (UNICEF), 27

5. Ibid., 26

6. Djamilah, Reni Kartikawati. (2014). Dampak Perkawinan Anak di Indonesia, Jurnal Studi Pemuda, 3(1), 2

7. Ibid. (1974). See also the Law of the Republic of Indonesia Number 1 Year 1974 of Marriage, 3.

8. Article 1 Convention on The Right of The Child, 1989

9. See also Article 1 of the Law of the Republic of Indonesia Number 35 Year 2014 of the amendement of the Law of the Republic of Indonesia Number 23 Year 2002 of Protection of the Child.

10. St. Shabina Tendean.(2018). Kewajiban Negara Peratifikasi Terhadap Ekslpoitasi Anak Berdasarkan United Nations Convention on the Rights of the Child 1989, Faculty of Law, Hasanuddin University, Thesis, See also Civil Law Book, 27.

11. Irma Setyowati. (1990). Aspek Hukum Perlindungan Anak. Jakarta, Bumi Aksara, p. 19 in ST Shabina Tendean, Ibid, 28
12. John Dirk Pasalbessy. (2017). Implementasi HakHak Anak di Indonesia, (Paper) Faculty of Law, Pattimura University, in Research Reported Iin Karita Sakharina, et.al., Implementasi Ratifikasi Konvensi Hak Anak Dalam Menangani Anak-Anak Korban Kekerasan dan Eksploitasi di Sulawesi Selatan, Research Institutes and Community Service of Hasanuddin University, 3

13. Ibid., 4

14. Djamilah, Reni Kartikawati, Dampak Perkawinan Anak di Indonesia, Op.Cit., 2

15. BPS, Kemajuan Yang Tertunda, Analisis data Perkawinan Usia anak di Indonesia, Op.Cit., 11

16. Ibid., p.11

17. Article 1 on CEDAW. (2002). Ian Brownlie, Goodwin-Gil, Basic Document on Human Rights, $4^{\text {th }}$ edition, Oxford University Press, 213

18. BPS, Op.Cit., 12

19. Article 16 on CEDAW

20. Iin Karita Sakharina. (2003). Human Rights Study on The Practices of Mixed Marriage Between Indonesian Women and Foreign Men, (Thesis) Norwegian Centre of Human Rights, Faculty of Law, University of Oslo, Norway, 16

21. Ibid., 14

22. Bappenas. Perlindungan Anak, Jakarta: National Planning and Development Agency, 20-11

23. Research Reported Iin Karita Sakharina, et.al., Op.Cit., 27-28. 